\title{
ATTEMPTED INTERSPECIFIC TRANSDUCTION OF ANTIBIOTIC RESISTANCE IN STAPHYLOCOCCI
}

\author{
Beverly A. Dean and R. E. O. Williams* \\ Bacteriology Department, St Mary's Hospital Medical School, Paddington, London W2 IPG
}

THE coagulase-negative staphylococci isolated from patients in hospital are commonly resistant to antibiotics (e.g., Corse and Williams, 1968), and it was of some interest to see whether resistance-determining factors could be transferred from such strains to Staphylococcus aureus. This paper reports a number of unsuccessful attempts.

\section{METHODS}

Phages were propagated by the methods described by Dean et al. (1973), and the number of plaque-forming units (pfu) was determined after spotting $0.01 \mathrm{~cm}^{3}$ of 10 -fold dilutions on to the phage-typing agar plates (prepared for us by Oxoid Ltd) previously seeded with a 6hour culture of the propagating strain.

Bacterial counts were determined from optical density readings with the help of standard curves.

In all attempted transduction experiments, cocci were used at a count estimated to be $2 \times 10^{7}$ colony-forming units per $\mathrm{cm}^{3}$ and phages at $1.4 \times 10^{7}$ pfu per $\mathrm{cm}^{3}$, giving a multiplicity of infection of 0.7 .

Despite a very large number of attempts it did not prove possible to find more than very few phages that lyse both coagulase-positive and coagulase-negative staphylococci. Trials were made (1) with the polyvalent K phage (no. NCTC7814; Krueger, 1932); (2) by the mixed culture technique described by Lacey (1972); (3) by the use of culture supernates, as described by Yu and Baldwin (1970), and (4) with phage 155 from our typing set (Dean et al., 1973) which lyses a staphylococcus no. M6499 (Mortensen, 1969) that is also sensitive to phages active on coagulase-positive staphylococci.

\section{RESULTS}

Phage K was propagated on two $S$. epidermidis strains (nos. 304 and 885) that were resistant to tetracycline $10 \mu \mathrm{g}$ per $\mathrm{ml}$. A portion $(1 \cdot 0-\mathrm{ml})$ of each phage filtrate was incubated with an equal volume of a 18-hour broth culture of each of four strains of $S$. aureus, all sensitive to tetracycline, in the presence of $0.04 \%$ calcium chloride, for $30 \mathrm{~min}$. at $37^{\circ} \mathrm{C}$. The mixture was centrifuged, and the deposit suspended in $2 \mathrm{ml}$ of nutrient broth containing $0.02 \mathrm{M}$ sodium citrate and incubated for 2 hours at $37^{\circ} \mathrm{C}$. The mixture was again centrifuged and the deposit suspended in $2.0 \mathrm{ml}$ of nutrient broth; $0.1-\mathrm{ml}$ volumes were seeded on to nutrientagar plates containing tetracycline $10 \mu \mathrm{g}$ per $\mathrm{ml}$ and incubated for 48 hours at $37^{\circ} \mathrm{C}$. No tetracycline-resistant colonies developed.

We used the same method in an attempt to transduce streptomycin resistance from a strain of $S$. aureus to one of $S$. epidermidis, employing a preparation of the K phage grown on streptomycin-resistant $S$. aureus. No resistant $S$. epidermidis colonies developed.

Subsequent attempts at intraspecific transduction with the $\mathrm{K}$ phage were also unsuccessful.

The same tetracycline-resistant $S$. epidermidis strains and streptomycin-resistant mutants of the tetracycline-sensitive $S$. aureus strains were grown together in nutrient broth (Lacey, 1972) for 18 hours and then subcultured on to nutrient agar containing tetracycline $10 \mu \mathrm{g}$ per $\mathrm{ml}$ and streptomycin $10 \mu \mathrm{g}$ per $\mathrm{ml}$ and incubated for 48 hours. No colonies developed.

Next we used two novobiocin-resistant, coagulase-negative strains (nos. A111 and A115) of the biotype referred to as " $S . a$ " in our previous paper (Dean et al. 1973); the cocci were

Received 20 May 1974; accepted 1 June 1974

* Present address: Public Health Laboratory Service, Colindale Avenue, London NW9 5EQ.

J. MED. MICROBIOL.-VOL. 7 (1974) 
incubated at $37^{\circ} \mathrm{C}$ for 4 hours in broth containing mitomycin $\mathrm{C} 0.5 \mu \mathrm{g}$ per $\mathrm{ml}$. The broth was spun and the supernate spotted on the nutrient agar previously seeded with strains (nos. 13596 and 14077) of $S$. aureus that were novobiocin sensitive and lysed by the supernate from the mitomycin broth. Following the transduction methods described by $\mathrm{Yu}$ and Baldwin (1970), we incubated the recipient strains together with the lytic supernates. The mixtures were centrifuged and the deposits subcultured to nutrient agar containing novobiocin $0.9 \mu \mathrm{g}$ per $\mathrm{ml}$, and incubated overnight at $30^{\circ} \mathrm{C}$. The results of a typical experiment are shown in the table; there was a very high frequency of spontaneous mutation to novobiocin resistance and no evidence of transduced resistance.

TABLE

Attempted transfer of novobiocin resistance by lytic supernates of coagulase-negative staphylococci to Staphylococcus aureus

\begin{tabular}{c|cc}
\hline $\begin{array}{c}\text { Recipient } \\
\text { strain: } \\
\begin{array}{c}\text { S. aureus } \\
\text { number }\end{array}\end{array}$ & $\begin{array}{c}\text { Supernate of } \\
\text { donor" } \\
\text { culture of } \\
\text { coagulase-negative } \\
\text { staphylococcus number }\end{array}$ & $\begin{array}{c}\text { Number of } \\
\text { novobiocin-resistant } \\
\text { mutants (cfu per ml) }\end{array}$ \\
\hline 13596 & $\ldots * *$ & 890 \\
13596 & A111 & 880 \\
13596 & A115 & 190 \\
14077 & A111 & 70 \\
14077 & A115 & 70 \\
\hline
\end{tabular}

* Control: lytic supernate not added.

Lastly we used phage 155 from our typing set grown on each of several coagulase-negative strains that were resistant to various antibiotics. These phage preparations were used in attempts to transduce resistance into the strain M6499 (Mortensen, 1969) which is sensitive to these $S$. epidermidis phages and, although coagulase-negative, has biochemical characters (including deoxyribonuclease production) that indicate that it is closely related to $S$. aureus. No resistant colonies were obtained. Phage 155 had previously been shown (Dean, unpublished) to be capable of transducing tetracycline resistance at $10 \mu \mathrm{g}$ per $\mathrm{ml}$ between coagulase-negative staphylococci.

\section{SUMMARY}

Various methods were used in attempts to transduce antibiotic resistance from coagulasenegative to coagulase-positive staphylococci, but none was successful.

\section{REFERENCES}

CoRse, J. AND WILlIAMS, R. E. O. 1968. Antibiotic resistance of coagulase-negative staphylococci and micrococci. J. clin. Path., 21, 722.

Dean, B. A., Williams, R. E. O., Hall, F. AND Corse, J. 1973. Phage typing of coagulasenegative staphylococci and micrococci. J. Hyg., Camb., 71, 261.

KRURGER, A. P. 1932. Heat inactivation of an antistaphylococcus bacteriophage. J. gen. Physiol., 15, 363.

LACEY, B. W. 1972. Transfer of chromosomal genes between staphylococci in mixed culture. J. gen. Microbiol., 71, 399.

MoRTENSEN, N. 1969. Studies in urinary tract infections. III. Biochemical characteristics of coagulase-negative staphylococci associated with urinary tract infections. Acta. med. scand., 186, 47.

Yu, L. AND BALDWIN, J. N. 1970. Intraspecific transduction in Staphylococcus epidermidis and interspecific transduction between Staphylococcus aureus and Staphylococcus epidermidis. Can. J. Microbiol., 17, 767. 